\title{
The Life Esidimeni tragedy: Constitutional oath betrayed
}

\author{
A Dhai, MB ChB, FCOG, LLM, PGDip Int Res Ethic, PhD \\ Steve Biko Centre for Bioethics, Faculty of Health Sciences, University of the Witwatersrand, Johannesburg
}

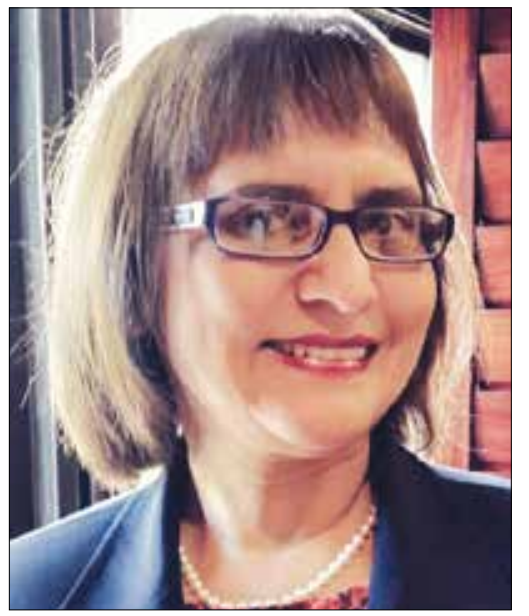

\section{Ames Dhai}

Editor

amaboo.dhai@wits.ac.za

The editorial in the previous issue of the South African Journal of Bioethics and Law discussed the Gauteng Mental Health Marathon Project (GMMP), or the Life Esidimeni (LE) tragedy, as it is better known, and examined the lip-service paid to South Africa (SA)'s Constitution by certain state actors. ${ }^{[1]}$ At the time of writing this editorial, an arbitration process, chaired by Justice Dikgang Moseneke, is underway with the families of the deceased and some of the survivors of the disaster. The number of dead has thus far increased to 143 , and 59 are as yet unaccounted for. During this process, SA has been witness to further startling revelations beyond those noted in the health ombud's report. ${ }^{[2]}$ In addition, stubborn evasion has been the pattern by state actors during this process. This editorial continues the discussion on SA's Constitutional promise, but focuses it on the office of Q D Mahlangu, previously the member of the executive council (MEC) for Gauteng Province in charge of health.

As a member of a provincial executive council, Mahlangu was required to take an oath (or solemn affirmation) in line with schedule 2 , section 5 of the Constitution of the Republic of $\mathrm{SA}^{[3]}$ when sworn in. The Constitutional requirements are as follows:

'Oath or solemn affirmation of Premiers, Acting Premiers and members of provincial Executive Councils:

The Premier or Acting Premier of a province, and each member of the Executive Council of a province, before the President of the Constitutional Court or a judge designated by the President of the Constitutional Court, must swear/affirm as follows:

I, A.B. swear/solemnly affirm that I will be faithful to the Republic of South Africa and will obey, respect and uphold the Constitution and all other law of the Republic; and I undertake to hold my office as Premier/Acting Premier/member of the Executive Council of the province of C.D. with honour and dignity; to be a true and faithful counsellor; not to divulge directly or indirectly any secret matter entrusted to me; and to perform the functions of my office conscientiously and to the best of my ability.'
According to the ombud's report, ${ }^{[2]}$ the MEC was not aware of the total number of patients who had died in a project that she had authorised during the 'conscientious' performance of a function of her office. While she indicated in an interview with the ombud during the enquiry that he headed into the LE tragedy that the decision was a collective one, and not hers individually, and that there were no dissenting views in their meetings, she is alleged by many to have said that 'her decision is final and non-negotiable and the project had to be done', and that she left no room for 'engagement'. Staff members felt powerless and had to deliver to her the outcome of a project they did not believe in - a cost reduction from ZAR320/day in $L E$, to ZAR112/day at the non-governmental organisations to which the patients were sent. He goes on to state that there was a general culture of fear and disempowerment among staff that hampered them from challenging or engaging with authority. There was an overwhelming revelation of frustration and disempowerment, which came from across all sectors of the department below the director's level, during oral evidence gathered in the enquiry.

The MEC was bound by the oath she took when sworn in as a public servant at the level of the provincial executive council to ensure the realisation of the Constitutional promises to the patients and families in the LE tragedy. Moreover, she was also bound to function conscientiously and with honour and dignity, and respect for the worth and value felt by and bestowed on persons. By not abiding by this oath, not only did she wrong the patients and families, but she also disgraced her office and brought it into disrepute. She abused the power of her office and used it to mete out a 'reign of terror' similar to that of a repressive state, resulting in moral distress for staff members who powerlessly tried to deliver to her the outcome of a project they did not believe in. Furthermore, instead of humanitarian considerations, the project focused on narrow economic ones.

Of note is that, during the interview, the MEC stated that 'when a policy decision is taken, you don't know how it will unfold and what is going to happen ... the risks associated with it.' Implementing a policy decision without having any idea of its feasibility and 'how it would unfold' contradicts the Ekurhuleni Declaration on Mental Health of April 2012, ${ }^{[4]}$ where a commitment was made that all users of mental-health services would participate in the planning, implementation, monitoring and evaluation of mental-health services and programmes. With proper planning that included all stakeholders, and assessing whether the policy was operationally and administratively feasible, possibly by a pilot programme, the tragedy could have been averted. The declaration also commits to physical infrastructure that is conducive to the needs and human rights of people with mental disorders and disabilities. As MEC, the ultimate responsibility resided with her - she did not ensure that their accommodation needs were provided for and that their human rights were respected. Providing equitable, 
cost-effective and evidence-based interventions is an additional commitment of the declaration. Deinstitutionalising patients into the community was an intervention in mental healthcare - however, when implemented, it was not evidence based.

Because the deinstitutionalising intervention was not evidence based, and because of her statement on not knowing how a policy decision could unfold, the GMMP can be likened to an experiment. One of the definitions of experiment is'a course of action tentatively adopted without being sure of its outcome.! ${ }^{\prime[5]}$ Therefore, the GMMP could be perceived as one massive experiment that included highly vulnerable subjects who, because of this vulnerability being exploited, suffered serious harms and wrongs. The entire project, with patients being herded and taken to 'concentration camps', as described by families, and subjected to cruel, degrading and inhumane conditions, is a distressing reminder of Hitler's Nazi war atrocities, where the vulnerable were considered to be subhuman, of lesser intelligence, of no moral status and lacking human dignity - and hence exploitable.

What is highlighted by this tragedy is the political appointment of a member of the provincial executive to run the provincial Department of Health who either did not understand or chose to ignore the Constitutional oath she took when sworn in. She ran her department similarly to an authoritarian leader in a repressive state, and betrayed that oath. Furthermore, she was not trained as a healthcare professional, and therefore had limited to no understanding of why health professionals have such a grave calling, and why they must abide by a much higher level of professionalism than those in other careers. Political appointments without any consideration of competence fail our patients and fail our country, and result in politics determining the ethics of healthcare - a moral pathology that must be eradicated for the ethical crisis that we find ourselves in to be comprehensively addressed.

1. Dhai A. After Life Esidimeni: True human rights protections or lip service to the Constitution? S Afr J Bioethics Law 2017;10(1):2-3. https://doi.org/10.7196/ sajbl.542

2. Makgoba MW. The Life Esidimeni disaster: The Makgoba report. PoliticsWeb. 1 February 2017. http://www.politicsweb.co.za/documents/the-life-esidimenidisaster-the-makgoba-report (accessed 10 July 2017).

3. South Africa. The Constitution of the Republic of South Africa, 1996. http://www. justice.gov.za/legislation/constitution/SAConstitution-web-eng.pdf (accessed 25 November 2017).

4. Department of Health, South Africa. The Ekurhuleni Declaration on Mental Health. April 2012. Appendix 3 of the National Mental Health Policy Framework and Strategic Plan 2013 - 2020. https://www.health-e.org.za/wp-content/ uploads/2014/10/National-Mental-Health-Policy-Framework-and-StrategicPlan-2013-2020.pdf (accessed 26 November 2017).

5. Oxford English Living Dictionaries. https://en.oxforddictionaries.com/definition/ experiment (accessed 25 November 2017).

S Afr J Bioethics Law 2017;10(2):40-41. DOI:10.7196/SAJBL.2017.v10i2.630 